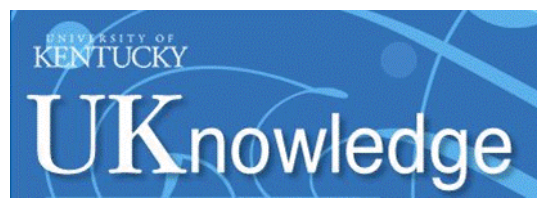

University of Kentucky

UKnowledge

Sanders-Brown Center on Aging Faculty

Publications

Aging

$1-2018$

\title{
Disturbance of Redox Homeostasis in Down Syndrome: Role of Iron Dysmetabolism
}

\author{
Eugenio Barone \\ Sapienza University of Rome, Italy \\ Andrea Arena \\ Sapienza University of Rome, Italy \\ Elizabeth Head \\ University of Kentucky, elizabeth.head@uky.edu \\ D. Allan Butterfield \\ University of Kentucky, david.butterfield@uky.edu \\ Marzia Perluigi \\ Sapienza University of Rome, Italy
}

Follow this and additional works at: https://uknowledge.uky.edu/sbcoa_facpub

Part of the Biochemical Phenomena, Metabolism, and Nutrition Commons, and the Neurosciences

Commons

Right click to open a feedback form in a new tab to let us know how this document benefits you.

\section{Repository Citation}

Barone, Eugenio; Arena, Andrea; Head, Elizabeth; Butterfield, D. Allan; and Perluigi, Marzia, "Disturbance of Redox Homeostasis in Down Syndrome: Role of Iron Dysmetabolism" (2018). Sanders-Brown Center on Aging Faculty Publications. 119.

https://uknowledge.uky.edu/sbcoa_facpub/119

This Article is brought to you for free and open access by the Aging at UKnowledge. It has been accepted for inclusion in Sanders-Brown Center on Aging Faculty Publications by an authorized administrator of UKnowledge. For more information, please contact UKnowledge@lsv.uky.edu. 


\title{
Disturbance of Redox Homeostasis in Down Syndrome: Role of Iron Dysmetabolism
}

\author{
Digital Object Identifier (DOI) \\ https://doi.org/10.1016/j.freeradbiomed.2017.07.009

\section{Notes/Citation Information} \\ Published in Free Radical Biology and Medicine, v. 114, p. 84-93. \\ (C) 2017 Elsevier Inc. All rights reserved.
}

This manuscript version is made available under the CC-BY-NC-ND 4.0 license https://creativecommons.org/licenses/by-nc-nd/4.0/.

The document available for download is the author's post-peer-review final draft of the article. 


\title{
Disturbance of redox homeostasis in Down Syndrome: role of iron dysmetabolism
}

\author{
Eugenio Barone ${ }^{1,2}$, Andrea Arena ${ }^{1}$, Elizabeth Head $^{3,4}$, D Allan Butterfield ${ }^{3,5}$, and Marzia \\ Perluigi ${ }^{1, *}$ \\ ${ }^{1}$ Department of Biochemical Sciences, Sapienza University of Rome, Italy \\ 2Universidad Autónoma de Chile, Instituto de Ciencias Biomédicas, Facultad de Salud, Avenida \\ Pedro de Valdivia 425, Providencia, Santiago, Chile \\ ${ }^{3}$ Sanders-Brown Center on Aging, University of Kentucky, Lexington, KY 40506 USA \\ ${ }^{4}$ Department of Neurology, University of Kentucky, Lexington, KY 40506 USA \\ ${ }^{5}$ Department of Chemistry, University of Kentucky, Lexington, KY 40506 USA
}

\begin{abstract}
Down syndrome (DS) is the most common genetic form of intellectual disability that leads in the majority of cases to development of early-onset Alzheimer-like dementia (AD). The neuropathology of DS has several common features with $\mathrm{AD}$ including alteration of redox homeostasis, mitochondrial deficits, and inflammation among others. Interestingly, some of the genes encoded by chromosome 21 are responsible of increased oxidative stress (OS) conditions that are further exacerbated by decreased antioxidant defense. Previous studies from our groups showed that accumulation of oxidative damage is an early event in DS neurodegeneration and that oxidative modifications of selected proteins affects the integrity of the protein degradative systems, antioxidant response, neuronal integrity and energy metabolism.

In particular, the current review elaborates recent findings demonstrating the accumulation of oxidative damage in DS and we focus attention on specific deregulation of iron metabolism, which affects both the central nervous system and the periphery. Iron dysmetabolism is a well-recognized factor that contributes to neurodegeneration; thus we opine that better understanding how and to what extent the concerted loss of iron dyshomestastis and increased OS occur in DS could provide novel insights for the development of therapeutic strategies for the treatment of Alzheimer-like dementia.
\end{abstract}

\section{Keywords}

Trisomy 21; oxidative stress; protein oxidation; redox proteomics; iron

*Corresponding author: Marzia Perluigi, PhD, Department of Biochemical Sciences, Sapienza University of Rome, P.le Aldo Moro, 5 00185 Rome (IT), Phone: +39 0649910885, Fax: +39 064440062, marzia.perluigi@ uniroma1.it. 


\section{Alzheimer-like dementia in Down Syndrome population}

Down syndrome (DS) is a congenital birth defect that arises by the complete or partial trisomy of Chr21 (trisomy21) and is the most prevailing genetic cause of intellectual disability with an incidence of around 1:800 births. The complete triplication of the entire Chr21 is not necessary to produce the clinical phenotype of DS individuals; indeed, the triplication of just a portion of the distal long arm, described as DS critical region (DSCR), has been identified as sufficient for this purpose [1]. The majority (95\%) of DS cases are caused by non-disjunction of chromosome in meiosis I, during the formation of gametes; while $3.2 \%$ and $1.8 \%$ of residual DS cases are caused, respectively, by translocation and mosaicism [2].

The effects of trisomy 21 vary widely from one individual to the other and not every DS subject show all the phenotypic features caused by trisomy. Therefore, it is conceivable to separate DS features in two types: i) those seen in all patients, for example cognitive decline or facial dysmorphology; and ii) those that have variable penetrance, such as the congenital heart defect that is observed in $40 \%$ of DS cases.

In addition to the chromosomal abnormality, it is believed that additional environmental factors could to play an important role in determining different phenotypes. The "gene dosage hypothesis" proposes that the overexpression of trisomic genes and their encoded proteins is directly responsible for the different phenotypical alterations in DS [3, 4]. The amplified developmental instability hypothesis" postulates that the presence of multiple phenotypes is caused by the effects of the overexpression of trisomic genes on dysomic genes leading to an imbalance in their expression [5]. So far, results obtained by the analysis of DS cases and the development of DS mouse models support both hypotheses. Therefore, the combination of these two hypothesis indicates a complex scenario in which the consistently over- or down-expression of a subset of dosage-sensitive genes lead to different phenotypic features.

The main pathological features include seizures, leukemia, vision problems, thyroid dysfunction, diabetes and dementia, specifically early onset Alzheimer disease (AD) (reviewed in [4]).

In the last decade, DS neuropathology has become an attractive field of research for a number of reasons: i) DS can be regarded as a human model of accelerated aging; ii) DS allows correlation between genetic defects and pathological phenotypes; iii) and DS neuropathology correlates with neurogenesis defects, brain development abnormalities and cognitive impairment.

Some of the most consistent and significant alterations in DS involve the brain, which demonstrates reduced neuronal content, reduced frontal lobe volume and narrowed superior temporal gyrus. DS individuals, after the age of 40, develop a type of dementia that is similar to $\mathrm{AD}$, the most common cause of dementia in the elderly population, with deposition of senile plaques containing amyloid beta-peptide (A $\beta)$, neurofibrillary tangles (NFTs) composed of hyperphoshorylated tau, and cholinergic and serotonergic reduction $[6$, 7]. The neurodegenerative process in DS population can be considered a "human model" of 
pre-clinical, early $\mathrm{AD}$ and could contribute to understanding the pathological mechanisms involved in the progression to late stage $\mathrm{AD}$. The deposition of $\mathrm{A} \beta$ plaques and NTFs are the most prominent and detrimental neuropathological changes in AD brain and occur in cortical regions that are important in acquiring, storing and retrieving information. These regions include temporal lobe structures, such as the hippocampus, as well as frontal and parietal regions.

Characteristic features in AD brain are weakening of synaptic networks, neuronal loss and increase of brain atrophy $[8,9]$. $A \beta$ and tau lesions affect several brain regions in DS, including prefrontal cortex, hippocampus, basal ganglia, thalamus, hypothalamus and midbrain and are believed to underlie the development of cognitive decline and dementia. However, although the depositions of $A \beta$ plaques have been observed in fetus and young DS individuals [10-12], signs of dementia are clearly manifested many years later.

Interestingly, a recent study demonstrated elevated amyloid levels that does not reach a plateau in the nondemented DS population. The rate of amyloid accumulation differs by preexisting amyloid burden and precedes atrophy or dementia in the DS population, similar to general $\mathrm{AD}$ progression, thus suggesting consistency of the $\mathrm{AD}$ pathophysiologic process in DS as well as in the general population [13].

The identification and characterization of the genes and proteins encoded on Chr21 is crucial to understand the mechanisms by which the chromosomal abnormality could contribute to the development of $\mathrm{AD}$ in $\mathrm{DS}$ individuals as well as in the general population. The entire sequence of human Chr21 is now known and there are 233 coding genes, 299 long noncoding genes (Ensembl release 78) and 29 microRNAs (miRBase release 21) [14]. After investigation with Swiss-Prot and analysis with Gene Ontology Annotation, the 207 proteins found encoded on Chr 21: i) take part in 87 different biological processes, and 11 proteins are involved in signal transduction; ii) have 81 different molecular functions among which DNA binding and transcription factor activity are the most prevalent with 15 proteins; iii) are localized in 26 different cellular components, nucleus and the plasma membrane with 19 and 15 proteins, respectively, are the most predominant cellular localizations [4].

\section{Oxidative stress in Down Syndrome}

Among putative mechanisms that contribute to the accelerated aging, cognitive and neuronal dysfunction in DS, the oxidative stress (OS) hypothesis has been recognized to affect neurogenesis and differentiation, connection and survival in the brain [6, 15-17]. Increased OS has been implicated in the development and progression of neurodegenerative diseases and several studies confirmed the accumulation of oxidative damage in the brains of both $\mathrm{AD}$ and DS subjects [18-20].

OS is a condition that results from either overproduction of reactive oxygen and nitrogen species (ROS/RNS), or by decreased antioxidant response. The presence of elevated fatty acids content in the nervous tissue, together with the high aerobic metabolic activity, are responsible of the brain susceptibility to undergo oxidative damage [21-23]. Accordingly, a strong correlation between higher OS levels and several cellular toxic processes in 
neurodegenerative conditions has been reported. ROS such as superoxide anion $\left(\mathrm{O}_{2}{ }^{-\bullet}\right)$, hydrogen peroxide $\left(\mathrm{H}_{2} \mathrm{O}_{2}\right)$, and hydroxyl radical $\left(\mathrm{HO}^{*}\right)$, are generated as by-products of aerobic respiration and various other catabolic and anabolic processes [24]. The major source of free radicals is the mitochondrial oxidative phosphorylation pathway, in which electron leakage from the electron transport chain causes the formation of $\mathrm{O}_{2}^{-\bullet}$ that, in turn, is converted by mitochondrial-resident $\mathrm{MnSOD}$ into $\mathrm{H}_{2} \mathrm{O}_{2}$ and $\mathrm{O}_{2}$ [25]. Indeed, dysfnction of complex I has been demonstrated to be one of the major responsible of overproduction of ROS in skin DS fibroblast isolated from both fetal and adult subjects [26].

In the cytosol, $\mathrm{H}_{2} \mathrm{O}_{2}$ can be efficiently removed by antioxidant systems such as catalase (CAT), glutathione peroxidase (GPX) and thioredoxin peroxidase.

Interestingly, triplication of several Hsa21 genes such as $S O D 1, A P P, B A C H 1, E t 2, C R$, $S 100 B$ among others are believed to be involved in the increased OS levels found in DS individuals and in the Ts65Dn mouse model [16].

$S O D 1$ is the gene encoding for the enzyme that catalyzes the conversion of $\mathrm{O}_{2}^{-\bullet}$ into $\mathrm{H}_{2} \mathrm{O}_{2}$ in the cytosol. The increase in SOD activity results in the formation of elevated levels of $\mathrm{H}_{2} \mathrm{O}_{2}$, and is not paralleled by similar elevation of CAT and GPX, thus leading to the overproduction of ROS. Accordingly, all DS tissues, in addition to the brain, display an altered SOD-1/GPX activity ratio [27] (Figure 1). SOD-1 was found at levels approximately $50 \%$ higher than normal in a variety of DS cells and tissues, including erythrocytes, B and T lymphocytes, and fibroblasts. Another major contributor to the OS hypothesis of neurodegeneration in DS is the triplication of $A P P$ that is thought to have a key role in the pathology of AD. However, triplication of $A P P$ does not necessarily lead to enhanced expression of APP and subsequent $A \beta$ accumulation, but it is strongly linked to A $\beta$ deposition in adult life. As expected, in DS individuals, increased APP gene expression leads to increased production of $A \beta[28,29]$, the major component of amyloid plaques that accumulate in brain in all DS individuals over 40 years of age. The levels of $A \beta(1-42)$ and $A \beta(1-40)$ are higher in DS plasma than controls and the ratio of $A \beta 42 / A \beta 40$ is lower in DS than in controls [29]. In addition, the same group demonstrated that decreasing levels of plasma $A \beta 42$, a decline in the $A \beta 42 / A \beta 40$ ratio, or increasing levels of $A \beta 40$ may be putative markers of conversion to $\mathrm{AD}$ in adults with $\mathrm{DS}$, possibly reflecting compartmentalization of $A \beta$ peptides in the brain. Several studies demonstrated that $A \beta$ is associated with the production of ROS [30, 31] (Figure 1), and also induces calciumdependent excitotoxicity, impairment of cellular respiration, and alteration of synaptic functions associated with learning and memory [32].

Moreover, it is worth to be mentioning that trisomy 21-induced ROS overproduction may itself alter APP processing, promoting intracellular accumulation of $A \beta$ [12]. Thus, protecting DS brain from ROS may be of therapeutic value, although antioxidant supplementation has failed to show efficacy in preventing dementia in this population [33, 34]. At the same time, overexpression of APP may promote mitochondrial dysfunction independently from aberrant $A \beta$ deposition, thus exacerbating OS conditions [22]. 
Results from our group and others also suggest the involvement of $B A C H 1$, encoded on $\mathrm{Chr} 21$, in the regulation of the antioxidant response in DS. BACH1 is a transcription repressor that plays an important role in the regulation of the expression of genes involved in the cell stress response. BACH1, under physiologic conditions, forms heterodimers with small Maf proteins (i.e., MafK, MafF and MafG), which bind the antioxidant response elements (AREs) of DNA, thereby inhibiting the expression of specific proteins (Figure 1). By contrast, increased OS levels suppress the function of BACH1 by promoting BACH1 nuclear export and enhancing the expression of its gene targets. When the intracellular heme levels increase, as under pro-oxidant condition, nuclear BACH1 binds heme and dissociates from the AREs thus allowing the expression of genes such as: quinone oxidoreductase-1 (NQO1), glutathione S-transferase (GST), glutamate-cysteine ligase (GCL) and heme oxygenase-1 (HO-1). It is likely that upregulation of $B A C H 1$ due to trisomy 21 could block the induction of antioxidant genes, therefore promoting OS increase in the cell.

OS markers have been found to be elevated in peripheral and CNS specimens of DS patients and animal models of the disease. Levels of TBARS, protein carbonyls, and advanced glycation end products were increased in the cortex from DS fetal brain compared with controls (reviewed in [16]). Accumulation of 8-hydroxy-2-deoxyguanosine, oxidized proteins and nitrotyrosine also was observed in the cytoplasm of cerebral neurons in DS [35]. At the peripheral level, the amount of isoprostane 8,12-iso-iPF2a, a specific marker of lipid peroxidation, is essentially elevated in urine samples from adults with DS [36].

Among different targets, free radical-mediated damage to proteins may be detrimental in aging and in age-related neurodegenerative diseases, because in the majority of cases, protein oxidation is a non-reversible phenomenon that therefore requires clearance systems for removal [37]. Further, the majority products of amino acids oxidation as well as other amino acid modifications cannot be directly repaired and must be selectively eliminated to prevent the accumulation of damaged, non-functional proteins. Only few enzymes exist for repairing oxidized amino acids, such as methione and cysteine. Generally, oxidation of proteins could affect protein expression and gene regulation, protein turnover, cell signaling, apoptosis, necrosis, etc., eventually leading to loss of cells and function [20].

\section{Proteomics and redox proteomics approach to study DS neuropathology}

The field of proteomics has significantly improved due to advances in the accuracy, sensitivity and speed of MS and to the expansion of bioinformatics [38]. However, the proteomics analysis of a given system is a complex task as the proteome is dynamic and is affected by both intrinsic and extrinsic factors [39]. In the last decade, much effort has been given to the analysis of protein changes in DS from the fetal stage, in order to identify the molecular targets that from one side can be involved in disease progression and on the other can be employed as prenatal diagnostic markers [22, 40-42]. Hence, the study of DS samples involved the use of different proteomics methods that employ a number of different steps for protein separation and identification of the proteins [41].

Gel-based two-dimensional electrophoresis (2DE) has been widely used in the analysis of both human brain samples and biofluids, becoming since its introduction the method of 
choice to perform differential protein expression analysis. The post-gel detection is achieved by the use of specific gel stains, which allow, by specialized software for image analysis, the matching and differential quantitation of gel spots. Target spots are excised from the gels and digested to peptides by proteolytic enzymes. Individual resolved spots are then sequentially analyzed by matrix assisted laser desorption/ionization time-of-flight (MALDITOF) MS or electrospray ionization tandem mass spectrometry (ESI-MS/MS) [38]. A further refinement of $2 \mathrm{DE}$ proteomics is represented by DIGE that uses the labeling of different protein mixture with specific fluorescent dyes, prior to sample separation [43].

Gel-free proteomics techniques allow the identification of proteins in complex mixtures using a combination of HPLC and MS. Gel-free analyses are commonly used on a standardized platform to compare proteome differences corresponding to disease phenotypes, molecular characteristics and responses to stimuli [44]. In addition, gel-free proteomics analyses are highly applied to the analysis of human biofluids for the quantitation of potential diagnostic markers. Among others, gel-free techniques applied to DS include, isotope-coded affinity tag (ICAT) and isobaric tags for relative and absolute quantitation (iTRAQ), which couple specific mass-tagging techniques and 2D LC-FTOrbitrap-MS, multidimensional protein identification technology (MudiPIT) that consists of a 2D-chromatographic separation by at least two orthogonal combinations prior to a ESI/MS identification process, and surface-enhanced laser desorption/ionization (SELDI), by which proteins of interest are bound to a specific surface before MS analysis by time-of-flight (TOF) mass spectrometry [43].

Since OS is an early event in the development and progression of DS neuropathology, our laboratory and others focused on the identification of specific brain target of oxidative damage that may contribute to the neurodegenerative process and also to establish a direct link between tissue specific oxidation and systemic oxidative damage [21, 22, 40, 41, 45, 46]. These studies took advantage of the use of a redox proteomics approach that is specifically dedicated to analysing irreversible oxidative modifications of proteins. The redox proteomics approach couples 2DE with immunochemical detection of oxidized proteins, followed by MS for protein identification. Proteins containing reactive carbonyl groups/3-NT/HNE are detected individually by $2 \mathrm{D}$-western blot analysis using antibodies that recognize a specific oxidative modification. The resulting gels and blots are analyzed by imaging software to obtain the differential protein oxidation (normalized on protein expression) between samples from the different conditions [38, 41].

The application of proteomics platforms in the past years led to the identification of several proteins whose alterations may play a crucial role in the development of DS [22]. The first proteomics studies were performed, in early 2000 by Lubec and co-workers employing 2DE separation on human fetal brain samples from DS subjects compared to age-matched controls. Most of the proteins found to be differentially expressed possess a structural role, suggesting the alteration of brain development process during DS, consistent with characteristic DS phenotypes [47]. Subsequent studies from the same laboratory led to the identification of proteins involved in energy metabolism and synaptic plasticity, known to be dysfunctional in DS [48-51]. Cenini and co-workers [52] analyzed the frontal cortex of DS subjects with or without significant AD pathology in comparison with age-matched controls. 
In this study, the alteration of common pathways between DS and AD pathology including energy metabolism, antioxidant response and proteostasis network have emerged [52].

Besides proteomics studies of human brain, the analysis of brain proteome from mouse models of DS also has been also performed in the last decade. In 2004 Kadota et al. performed a 2-DE proteomics on TT2F (TT2F/hChr21) mouse embryonal stem cells identifying the alterations of structural proteins, heat shock/stress proteins, degradation proteins and enzymes for energy and macromolecular metabolism [53]. Those results were consistent with human data, supporting once again the involvement of the proteostasis network and energy metabolism in the altered development of DS brain. In addition, the Lubec group in 2006 [54] analyzed the quantitative variations of proteins in the 141G6 mouse model of DS, and Wang et al. [55], performed an iTRAQ proteomic study on embryonic stem cells from the Tc1 mice, both demonstrating a high correlation between expression differences occurring in mouse models of DS and human DS tissue. In 2014 Ishihara and colleagues found that a dysregulation of protein expression is associated with abnormalities during embryonic life in Ts1Cje mice [56].

In parallel to the proteomics analysis of human and mouse models brain samples of DS, several groups investigated the alterations of proteome from biofluids [amniotic fluid (AF) and plasma from mothers carrying DS fetus and plasma and saliva from DS subjects] with the aim to understand the mechanisms involved in DS development and to recognize putative markers for prenatal diagnosis. Tsangaris et al. performed initial studies on biofluids in 2006 on amniocytes isolated from AF from mothers carrying a DS fetus [57] and identified proteins differentially expressed in DS pregnancies that may be involved in DS fetal alterations. Other groups performed further studies on AF or amniocytes from DS pregnancies, by LC-ESI-MS/MS and SILAC techniques, confirming that the protein profile is altered in the AF from DS cases and obtaining reproducible data that may be employed as potential diagnostic tools [58, 59].

Moreover, a number of different studies were also conducted on maternal plasma/serum of DS pregnancies employing a wide-range of proteomics techniques including iTRAQ, singlereaction-monitoring (SRM) tandem mass spectrometry-based assay, MuDipit, 2D-DIGE, SELDI-TOF and 2DE approaches [60-67]. These studies identified the alteration of several maternal plasma-resident proteins during DS gestations that correlate with altered DS development and might represent non-invasive diagnostic markers of DS pathology. The candidate serum biomarker proteins detected can be categorized into three major functional groups: protease inhibitors, acute-phase response proteins, and serum carrier proteins. Many of the proteins identified have been previously implicated as playing a role in developmental disorders and DS

Accumulating evidence has demonstrated a major role of OS in DS clinical outcomes [16, 40]. Our laboratory applied redox proteomics to shed light into the molecular pathways perturbed by OS, which may play a key role in the neurodegenerative phenomena. In 2012, we investigated protein carbonylation levels in young DS (average 24ys) compared to healthy subjects obtaining data about specific targets of protein oxidation and their potential contribution to the neuropathology [46]. We found increased carbonylation of six proteins 
identified by MS: ubiquitin carboxy-terminal hydrolase L1 (UCH-L1); cathepsin D; 78-kDa glucose-regulated protein 78; V0-type proton ATPase subunit B, brain isoform; glial fibrillary acidic protein; and succinyl CoA:3-ketoacid-coenzyme A transferase 1 mitochondrial. Interestingly, the majority of oxidized proteins, including glucose-regulated protein 78; UCH-L1; cathespin D; V0-type proton ATPase subunit B, brain isoform; and glial fibrillary acidic protein, are members of the intracellular quality-control system [68, 69]. We suggest that chronic exposure to OS leads to the impairment of the systems, ubiquitin proteasome system (UPS) and the autophagy lysosome system (ALS), involved in the removal of unfolded/misfolded proteins and toxic protein aggregates [70-72]. In support to this hypothesis, we analyzed proteasome activity and autophagic flux in DS brain samples, demonstrating the reduced functionality of both these degradative pathways [46]. Thus, it is reasonable to suggest a close relationship between OS and protein misfolding in DS brain, implying that these events might be central for the progression of AD-like neuropathology in DS subjects.

Since increased lipid peroxidation is one of the main events causing redox imbalance in neurodegenerative diseases [73], we employed a redox proteomics approach to identify specific targets of 4-hydroxynonenal (HNE) modifications in the frontal cortex from DS cases, prior and after development of AD pathology [21]. All the identified proteins are involved in in intracellular quality control systems (PQC), cytoskeleton network, energy metabolism, and antioxidant response. Overall, our results demonstrate that oxidative damage is an early event in DS, and dysfunction of PQC may be critical to make neurons more vulnerable to oxidative damage that, once accumulates, contributes to the neurodegenerative process. Further, considering that the majority of proteins have been already demonstrated to be oxidized in $\mathrm{AD}$ brain, our results strongly support the notion that aberrant protein oxidation in DS may contribute to $\mathrm{AD}$ development $[16,41]$.

In agreement with our results, previous studies by Ishihara et al. [100] on primary cultured astrocytes and neurons from the Ts1Cje mouse model identified by redox proteomics target proteins that were modified by two lipid peroxidation derived products, 3- hydroperoxy-9Z, 11E-octadecadienoic acid (13-HPODE), and 4-HNE [74]. Authors found eight proteins in total as putative 13-HPODE- and 4-HNE-modified proteins: ATP synthase mitochondrial F1 complex b-subunit, a- and g-enolase, triosephosphate isomerase 1, neurofilament light polypeptide, a-internexin,, peroxiredoxin 6 , phosphoglycerate kinase 1 and TPI1. The proteins identified were classified into three categories according to their function, proteins involved in ATP synthesis, proteins part of the neuronal cytoskeleton, and antioxidant enzymes. These results are consistent with increased lipid peroxidation [52], decreased ATP content, depletion of antioxidants and aberrant cytoskeletal rearrangement occurring in DS and $\mathrm{AD}[16,53]$, suggesting that these modifications could lead to neurodegeneration and to reduced cognitive performance. In addition, further studies in DS brain and in Ts65Dn mice brain supported the role of BACH1 in the control of HO-1, one of the main components of the heme degradation pathway with a powerful antioxidant function [75]. In particular, increased BACH1 levels, as result of HSA21 trisomy, leads to the dysregulation of HO-1, which, in turn, contributes to the early increase of oxidative stress in DS and provide a potential mechanistic explanation for increased protein carbonyls and protein-bound HNE in DS $[21,75]$. 
In recent years, an increasing number of studies have been focused into establishing a direct link between tissue-specific oxidation and the oxidative damage of protein components of biofluids, since biofluids represents a valid source of information on pathology onset and progression in living patients [44]. Correlations between total levels of oxidation markers in human brain and biofluids, such as amniotic fluids or plasma have been reported in DS pregnancies [40]. Our laboratory contributed to the analysis of AF in DS pregnancies evaluating a set of oxidative stress biomarkers that could demonstrate the early occurrence of oxidative damage since the fetal stage [45]. Accordingly, we measured specific targets of protein carbonylation identifying specific proteins that showed increased oxidation in AF from mother carrying DS fetuses compared with healthy controls. The proteins identified by redox proteomics are involved in iron homeostasis (ceruloplasmin and transferin), lipid metabolism (zinc-a2- glycoprotein, retinol-binding protein 4 and apolipoprotein A1) and inflammation (complement C9, a-1B-glycoprotein, collagen a-1V chain). We suggest that the increased oxidation of specific proteins could correlate with some characteristic features of DS, including early aging, cognitive impairment and also increased risk for cancer and immunodeficiency [16]. Our study further demonstrates that OS occurs early in the pathogenesis of DS and might play a crucial role in the severity of DS phenotypes. Some of the results obtained by redox proteomics are further described in the following section, with particular emphasis on iron dysmetabolism.

\section{Iron dysmetabolism in Down Syndrome}

Redox proteomics studies from our group showing that both ceruloplasmin $(\mathrm{Cp})$ and transferrin (Tf) were oxidatively modified in AF from women carrying DS pregnancy, which possibly resulted in impaired functionality, suggested a link between increased oxidative stress levels and the defects of iron metabolism in DS [45].

In mammals iron is an important cofactor for several enzymes. Heme iron, in particular, is involved in the regulation of various cellular functions, such as respiration, proliferation, and differentiation [76]. Iron also modulates specific brain functions by increasing the release and turnover of dopamine and other neurotransmitters [77]. The brain is arguably the most metabolically active organ in the body and its internal concentration of iron is exceptionally high particularly during the phases of neurodevelopment due to iron's role in myelinogenesis [78]. Indeed, a lack of iron prevents the construction of neural connections and the synthesis of neurotransmitters, including dopamine, and leads to insufficient energy for a rapidly growing organ [79]. In contrast, excessive amounts of iron can trigger the formation of highly toxic oxygen radicals through Fenton reaction, which cause protein oxidation, lipid peroxidation and DNA damage finally compromising cell viability and promoting programmed cell death [77, 80, 81]. These events are characteristic of neurodegenerative processes [82].

Iron deficiency anemia in infants, which is estimated to affect $3 \%$ of those aged $<6$ months, contributes to a range of neurological disorders and manifests clinically as cognitive, motor and social impairments [83-85]. Similarly, although less evidence is available, high levels of redox-active iron in the brain have been associated with neurodegenerative disorders, most notably Parkinson and AD, yet a gradual increase in brain iron seems to be a feature of 
normal ageing [86]. Increased brain iron levels might result from intake of infant formula that is excessively fortified with iron, thereby altering the trajectory of brain iron uptake and amplifying the risk of iron-associated neurodegeneration in later life [86]. Accumulating evidence also suggests that impaired iron homeostasis is an early event in AD progression. Iron dyshomeostasis leads to a loss of function in several enzymes requiring iron as a cofactor, the formation of toxic oxidative species, and the elevated production of betaamyloid proteins [87].

With regard to DS pathology, the role of iron has not been clarified. Indeed, a lack of critical information especially in the brain, as in the case for $\mathrm{AD}$ subjects, renders the field still obscure but simultaneously fascinating. The evaluation of iron or iron-associated proteins levels in circulating fluids, however, suggests that iron metabolism dysregulation occurs in DS subjects. In particular, the main outcomes are represented by a reduction of both total iron and Tf levels [88-93].

According to a recent paper, DS patients show increased levels of serum ferritin but decreased levels of Tf. Furthermore, despite a slight reduction of total iron content, increased levels of free redox-active iron in both plasma and erythrocytes were found [90]. In addition, increased iron levels were significantly associated with increased lipid peroxidation products such as F2-isoprostane and a worsening of cognitive functions [90]. In agreement, a previous study comparing DS and DS/AD subjects showed increased plasma ferritin concentration in $\mathrm{DS} / \mathrm{AD}$, and the authors proposed that the onset of AD-like dementia in DS may possibly be related to the increased uptake and deposition of iron following alteration in plasma iron transport [91].

The mean corpuscular volume of erythrocytes in persons with DS is larger than normal in the absence of anemia. Red blood cell survival half time seems to be substantially shorter than normal in many of these patients. These findings thus suggest that erythrocytes have a younger mean age in persons with DS. The increased red blood cell turnover in this population may indicate an accelerated aging process of red blood cells and can contribute to the increase of redox-active iron in blood whether not compensated by functioning transport or storage [89].

The link between peripheral and central iron level regulation is something still under investigation, and with regard to the role of iron either in DS brain development or in DSassociated neuropathology, only a few papers exists. In particular, the oxidative impairment of proteins involved in iron metabolism found by redox proteomics analyses was helpful in understanding the link among oxidative stress, iron dysmetabolism and neurological deficits.

Iron is mainly absorbed in the duodenum and upper jejunum. The uptake of nutritional iron involves reduction of $\mathrm{Fe}^{3+}$ in the intestinal lumen by ferric reductases [such as Dcytb (duodenal cytochrome $b$ )] and the subsequent transport of $\mathrm{Fe}^{2+}$ across the apical membrane of enterocytes by a transporter protein called divalent metal transporter 1 (DMT1). Then, iron within the enterocyte is released via ferroportin into the bloodstream [94]. The ferroportin-mediated efflux of $\mathrm{Fe}^{2+}$ is coupled by its re-oxidation to $\mathrm{Fe}^{3+}$, catalysed by the membrane-bound ferroxidase such as hephaestin its plasma homologue C) [95] (Figure 2). 
$\mathrm{Cp}$ is a glycoprotein characterized as a multicopper ferroxidase, due to the fact that $\mathrm{Cp}$ contains $95 \%$ of the copper in the plasma. The essential role of the ferroxidase activity of $\mathrm{Cp}$ in iron release from cells was attributed to facilitation of loading of the metal ion onto transferrin, which only binds $\mathrm{Fe}^{3+}$. However, a new molecular connection between $\mathrm{Cp}$ and ferroportin has been established by the finding that ferroxidase activity is required to stabilize ferroportin at the cell surface. Ferroxidase-active $\mathrm{Cp}$ stabilizes ferroportin at the plasma membrane supporting iron export; on the other hand, the absence of $\mathrm{Cp}$ or the presence of an inactive $\mathrm{Cp}$ lead to degradation of ferroportin in specific cell types [96].

To note, in the brain, $\mathrm{Cp}$ is expressed as a glycosylphosphatidylinositol (GPI)-linked form in astrocytes [97], where $\mathrm{Cp}$ is the only existing ferroxidase [98]. In the absence of Cp activity, the ferrous iron that enters the CNS cannot be oxidized and is internalized in large amount, through a transferrin-independent, non-regulated pathway [99]. The excess import of iron, associated to its export inability due to ferroportin malfunction in the absence of $\mathrm{Cp}$, leads to the remarkable accumulation of iron within astrocytes observed in neurodenegerative diseases [100]. Thus, it is reasonable to think that iron sequestration by astrocytes may induce iron deficiency and death in neurons, which are astrocyte-depended for iron acquisition $[98,100]$.

In the bloodstream, iron is transported bound to Tf, a plasma homodimeric beta-globulin that binds two ferric iron ions with exceedingly high affinity and maintains $\mathrm{Fe}^{3+}$ in a redox-inert state ready to be delivered into tissues [101] (Figure 1). Soluble Tf-Fe complexes are recognized by transferrin receptor 1 (TfR1) and 2 (TfR2) [102], two transmembrane disulfide-linked glycoproteins encoded by distinct genes sharing $45 \%$ homology. The affinity of TfR 2 for diferric $\mathrm{Tf}$ is 30 times lower to that of TfR1, suggesting that the contribution of TfR2 to intracellular Fe uptake is not as critical compared to TfR1 [103].

Following binding of $\mathrm{Fe}^{3}$ to TfRs, the TfR-Tf- $\mathrm{Fe}^{3+}$ complexes are internalized within the cell by endosomal recycling vesicles. Endosomal $\mathrm{Fe}^{3+}$ is then reduced into $\mathrm{Fe}^{2+}$ by metalloreductases and released inside the cell upon endosome acidification, while the TfR$\mathrm{Tf}$ complex is recycled to the plasma membrane. Here, $\mathrm{Tf}$ dissociates from TfR, and is used to repeat the cycle $[104,105]$. Meanwhile, cytoplasmic $\mathrm{Fe}^{2+}$ is transported to the mitochondria where it takes part in the biosynthesis of heme, which is the prosthetic group of several proteins including globins and cytochromes [105]. Indeed, iron incorporation into heme moieties, other than its importance for the maintenance of globins and cytochromes biological functions, represents one of the highly conserved evolutionary mechanisms through which $\mathrm{Fe}^{2+}$ toxicity is limited [105].

When intracellular labile Fe increases above a certain threshold level, its pro-oxidant activity must be controlled to avoid cytotoxicity. This aspect is mainly regulated by ferritins complexes. Ferritin is a protein complex formed by a 24-subunit multimer - a combination of ferritin heavy (FTH1) and light (FTL) chains - that, thanks to its ferroxidase activity, first converts $\mathrm{Fe}^{2+}$ into $\mathrm{Fe}^{3+}$ and then safely concentrates intracellular iron in a mineralized, redox-inactive form for later use (reviewed in $[105,106])$. Notably, ferritin-bound iron cannot be utilized by the cell. Consequently, iron must be released from ferritin to be biologically useful, usually through lysosomal degradation of ferritin $[105,106]$. Ferritin 
protein turnover is a constant process in cells. While the rate of ferritin degradation appears to be the same in iron-deficient and iron-replete conditions, the delivery mechanism of ferritin to lysosomes seems to be different: autophagy is responsible for delivering ferritin to the lysosome during iron deficiency, whereas a non-autophagic pathway dominates during iron sufficiency [106].

Defects of iron metabolism in DS appear early during pregnancy. Changes in AF represent a reliable index of the physiological condition of the fetus. The biochemical composition of AF, routinely used for prenatal diagnosis, is modified throughout pregnancy and its protein profile reflects both physiological and pathological changes affecting the fetus and the mother [107].

Evaluation of iron levels in AF revealed a significant increase of the catalytic $\mathrm{Fe}^{2+}$ form levels in mothers carrying DS fetuses, thus suggesting that $\mathrm{Fe}^{2+}$ can be one of the markers of a DS pregnancy [108]. Indeed, high catalytic $\mathrm{Fe}^{2+}$ may result in additional oxidative stress in DS-carrying mothers. Therefore, removing excess catalytic iron in amniotic fluid may possibly help to decrease the oxidative stress in DS pregnancies and to improve fetal prognosis [108].

In agreement with the above sentences, the evaluation of protein carbonyls and HNE-bound protein adducts were significantly increased in AF from women carrying DS fetuses with respect to AF from women carrying normal foetuses, indicating that both protein and lipid peroxidation pathways were enhanced even at the fetal stage in DS [45]. Further, we showed by redox proteomics that both $\mathrm{Cp}$ and $\mathrm{Tf}$ undergo oxidative modifications in $\mathrm{AF}$, which impair their functionality [45]. The ferroxidase activity confers $\mathrm{Cp}$ with a relevant antioxidant power and a significant role in iron homeostasis because ferrous ions, entering Fenton reactions, take part in an OS cascade [109]. Although fundamental for normal brain activity, $\mathrm{Fe}^{2+}$ may induce neuronal injury by catalyzing the conversion of hydrogen peroxide into highly reactive hydroxyl free radical. During exposure to OS, it has been suggested that substantial Cp inactivation may occur and free copper ions could be released [110, 111]. Furthermore, as explained above, $\mathrm{Cp}$ is required for ferroportin stabilization and correct functioning. In this scenario, the oxidative-induced impairment of $\mathrm{Cp}$ could contribute to accumulation of $\mathrm{Fe}^{2+}$ in astrocytes [100] and lead to neuronal damage. Therefore, impaired $\mathrm{Cp}$ may cause the propagation of free radical-mediated damage to other macromolecules upon exposure to OS.

Coupled to Cp, the observed oxidation of Tf in AF from women carrying DS fetuses [45] clearly suggest the disruption of iron metabolism early in DS. In fact, reduced $\mathrm{Fe}^{2+}$ oxidation to $\mathrm{Fe}^{3+}$ (mediated by $\mathrm{Cp}$ ) and its further transport (mediated by $\mathrm{Tf}$ ) might be responsible of impaired Fe storage, which possibly initiates multiple redox reactions that damage living cells via various pathways, resulting in an exacerbated OS condition that contributes to the development of deleterious DS phenotypes. Defective Tf, could also be implicated in a reduction of iron flux to the brain, promoting a condition of iron deficiency that frequently results in hypomyelination $[84,112]$. Iron deficiency, can result in cognitive and motor impairments that last throughout life. In addition, impairment of Tf, also could impact the synthesis of the heme moiety, which is an essential component of several 
proteins. Indeed, $\mathrm{Tf}$ is taken up by neurons through TfR1-mediated endocytosis, and, as noted above, diferric-Tf mediated transport provides the predominant source of iron for neurons [113].

As discussed previously, iron is an essential part of the prosthetic heme, and most of the iron provided by diet is used in heme biosynthesis and loaded into nascent hemoglobin or cytochromes [105]. Dietary Fe can also be extracted from heme, which involves most probably the catabolism of heme by the enzyme HO, allowing for Fe extraction and subsequent transport (Figure 2). Recycling of $\mathrm{Fe}^{2+}$ extracted from the prosthetic heme groups is therefore essential to maintain $\mathrm{Fe}$ homeostasis [105].

Two HO isoforms exist: an inducible form, named HO-1 and the constitutive one, named HO-2. HO-1 and HO-2 catalyze the same reaction, namely the transformation of ironprotoporphyrin-IX-alpha (heme) into equimolar amount of $\mathrm{Fe}^{2+}$, carbon monoxide (CO), and biliverdin-IX-alpha [114]. However, they seem to play different roles in protecting tissues against injuries [115]. The most convincing hypothesis suggests that controlled HO-1 induction plays a pivotal role in the earliest stages of cellular responses to tissue damage (oxidative stress, inflammation, heat shock), whereas HO-2 is constitutively expressed and is primarily involved in maintaining cell heme homeostasis [115-118].

In DS brain, despite increased OS levels, no changes in HO-1 protein levels has been observed in young subjects, whereas increased levels characterize adult DS subjects undergoing AD-like neurodegeneration. Interestingly, increased of HO-1 in DS/AD subjects is not comparable with that observed in $\mathrm{AD}$ subjects. This phenomenon seems likely linked to the trisomy of chr21, which encodes for the nuclear repressor of HO-1 gene, BACH1 [75].

In terms of iron metabolism, repression of HO-1 in DS would reduce the extent of Fe extraction from heme, which coupled with impaired transport and storage, might possibly represent an additional mechanism contributing to neurodegeneration. Indeed, heme is able to promote programmed cell death in response to proinflamamtory stimuli [119-121]. This deleterious effect is driven by Fe [122], although it is not clear if Fe must be released from heme to become cytotoxic or whether cytotoxicity can be exerted also by Fe within the context of the protoporphyrin ring of heme or both [123]. Considering that DS brain shows a marked pro-inflammatory state [124], this phenomenon could represent a conceivable mechanism occurring in DS.

Although no additional evidence is available with regard to the functioning of proteins belonging to iron metabolism in DS brain, there is an observation coming out from redox proteomics analyses, which could be further explored to shed light on the iron homeostasis in the CNS in DS. Indeed, oxidation of $\mathrm{V}_{0}$-type proton ATPase [46] as well as its polyubiquitinylation [42] were increased in DS brain. This proton pump is essential for acidification of vescicles in the endocytic pathway, and therefore the oxidation of the $\mathrm{V}_{0^{-}}$ ATPase pump could lead to dysfunction of autophagy. Mutation of ATPase genes is a wellrecognized risk factor for autophagy related neurodegenerative diseases [125, 126]. It is reasonable to speculate that once oxidized V0-ATPase has altered ability to regulate intracellular $\mathrm{pH}$ thus affecting proper endosomes/lysosomes functionality and autophagy, as 
was previously seen in a PD model [127]. Since Fe is extracted from TfR/Tf-Fe complexes through acidification of the endolysosomal compartment [105], alteration of the endosome environment could further contribute to iron dysregulation in the brain.

In a similar manner heme complexes converges at the endolysosomal compartment, where heme is extracted [128, 129]. By this reason, reduced heme catabolism because of BACH1related repression of HO-1 and the hypothesized reduction of heme extraction due to impairment of endosomal acidification, would favour heme accumulation and its associated neurotoxic effects [119-121].

Finally, relevant for DS, in a previous study it has been shown that APP possesses ferroxidase activity mediated by a conserved $\mathrm{H}$-ferritin-like active site, which is inhibited specifically by $\mathrm{Zn}^{2+}$ [130]. Indeed, like Cp, APP: (1) catalytically oxidizes $\mathrm{Fe}^{2+}$; (2) loads $\mathrm{Fe}^{3+}$ into transferrin; and (3) has a major interaction with ferroportin [130]. Ablation of APP in primary neurons induces marked iron retention. Furthermore, unlike normal mice, $\mathrm{APP}^{-/-}$ mice are vulnerable to dietary iron exposure, which causes $\mathrm{Fe}^{2+}$ accumulation and $\mathrm{OS}$ in cortical neurons. Paralleling iron accumulation, APP ferroxidase activity in AD post-mortem neocortex is inhibited by endogenous $\mathrm{Zn}^{2+}$, which has been demonstrated to originate from $\mathrm{Zn}^{2+}$-laden amyloid aggregates and correlates with $\mathrm{A} \beta$ burden [130]. Unfortunately, the role of $\mathrm{Zn}$ in DS brain is yet to be investigated. However, because DS is characterized by APP overexpression and due to the similarity between DS and AD neuropathology, it is conceivable that a similar mechanism could occur in DS brain, thus leading to brain iron dys-homeostasis.

\section{Concluding remarks}

The role of OS in neurodegeneration is well recognized, but intriguingly, we suggest that DS represents a special case of genetically encoded OS. Indeed, there are a number of trisomic genes, that directly or indirectly affects ROS levels, either by causing increased ROS production and decreasing the antioxidant response. This picture might be revisited in light few recent evidences suggesting the role of iron dysregulation in DS neuropathology. Accordingly, dysregulation of iron metabolism associated with OS and cellular damage is viewed as a common event in several neurodegenerative disorders. Iron dyshomeostasis leads to a loss of function in several enzymes requiring iron as a cofactor, the formation of toxic oxidative species, and the elevated production of beta-amyloid proteins among other mechanism of neurotoxicity.

However, the molecular mechanisms linking iron dysregulation to neurodegeneration in DS are still poorly understood mainly for paucity of published data and additional research is required.

\section{References}

1. Shapiro BL. The Down syndrome critical region. J Neural Transm Suppl. 1999; 57:41-60. [PubMed: 10666667]

2. Antonarakis SE, Petersen MB, McInnis MG, Adelsberger PA, Schinzel AA, Binkert F, Pangalos C, Raoul O, Slaugenhaupt SA, Hafez M, et al. The meiotic stage of nondisjunction in trisomy 21: 
determination by using DNA polymorphisms. Am J Hum Genet. 1992; 50:544-550. [PubMed: 1347192]

3. Antonarakis SE, Lyle R, Chrast R, Scott HS. Differential gene expression studies to explore the molecular pathophysiology of Down syndrome. Brain Res Brain Res Rev. 2001; 36:265-274. [PubMed: 11690624]

4. Antonarakis SE, Lyle R, Dermitzakis ET, Reymond A, Deutsch S. Chromosome 21 and down syndrome: from genomics to pathophysiology. Nat Rev Genet. 2004; 5:725-738. [PubMed: 15510164]

5. Iannello RC, Crack PJ, de Haan JB, Kola I. Oxidative stress and neural dysfunction in Down syndrome. J Neural Transm Suppl. 1999; 57:257-267. [PubMed: 10666681]

6. Lott IT. Neurological phenotypes for Down syndrome across the life span. Prog Brain Res. 2012; 197:101-121. [PubMed: 22541290]

7. Wisniewski HM, Rabe A. Discrepancy between Alzheimer-type neuropathology and dementia in persons with Down's syndrome. Ann N Y Acad Sci. 1986; 477:247-260. [PubMed: 2949682]

8. Serrano-Pozo A, Frosch MP, Masliah E, Hyman BT. Neuropathological alterations in Alzheimer disease. Cold Spring Harb Perspect Med. 2011; 1:a006189. [PubMed: 22229116]

9. Spires-Jones TL, Hyman BT. The intersection of amyloid beta and tau at synapses in Alzheimer's disease. Neuron. 2014; 82:756-771. [PubMed: 24853936]

10. Head E, Lott IT, Wilcock DM, Lemere CA. Aging in Down Syndrome and the Development of Alzheimer's Disease Neuropathology. Curr Alzheimer Res. 2016; 13:18-29. [PubMed: 26651341]

11. Head E, Powell D, Gold BT, Schmitt FA. Alzheimer's Disease in Down Syndrome. Eur J Neurodegener Dis. 2012; 1:353-364. [PubMed: 25285303]

12. Wiseman FK, Al-Janabi T, Hardy J, Karmiloff-Smith A, Nizetic D, Tybulewicz VL, Fisher EM, Strydom A. A genetic cause of Alzheimer disease: mechanistic insights from Down syndrome. Nat Rev Neurosci. 2015; 16:564-574. [PubMed: 26243569]

13. Lao PJ, Handen BL, Betthauser TJ, Mihaila I, Hartley SL, Cohen AD, Tudorascu DL, Bulova PD, Lopresti BJ, Tumuluru RV, Murali D, Mathis CA, Barnhart TE, Stone CK, Price JC, Devenny DA, Mailick MR, Klunk WE, Johnson SC, Christian BT. Longitudinal changes in amyloid positron emission tomography and volumetric magnetic resonance imaging in the nondemented Down syndrome population. Alzheimers Dement (Amst). 2017; 9:1-9. [PubMed: 28603769]

14. Griffiths-Jones S. The microRNA Registry. Nucleic Acids Res. 2004; 32:D109-111. [PubMed: 14681370]

15. Cenini G, Dowling AL, Beckett TL, Barone E, Mancuso C, Murphy MP, Levine H 3rd, Lott IT, Schmitt FA, Butterfield DA, Head E. Association between frontal cortex oxidative damage and beta-amyloid as a function of age in Down syndrome. Biochim Biophys Acta. 2012; 1822:130 138. [PubMed: 22009041]

16. Perluigi M, Butterfield DA. Oxidative Stress and Down Syndrome: A Route toward AlzheimerLike Dementia. Curr Gerontol Geriatr Res. 2012; 2012:724904. [PubMed: 22203843]

17. Lu J, McCarter M, Lian G, Esposito G, Capoccia E, Delli-Bovi LC, Hecht J, Sheen V. Global hypermethylation in fetal cortex of Down syndrome due to DNMT3L overexpression. Hum Mol Genet. 2016; 25:1714-1727. [PubMed: 26911678]

18. Barone E, Head E, Butterfield DA, Perluigi M. HNE-modified proteins in Down syndrome: Involvement in development of Alzheimer disease neuropathology. Free Radic Biol Med. 2016

19. Di Domenico F, Barone E, Perluigi M, Butterfield DA. The Triangle of Death in Alzheimer's Disease Brain: The Aberrant Cross-Talk Among Energy Metabolism, Mammalian Target of Rapamycin Signaling, and Protein Homeostasis Revealed by Redox Proteomics. Antioxid Redox Signal. 2016

20. Butterfield DA, Perluigi M, Reed T, Muharib T, Hughes CP, Robinson RA, Sultana R. Redox proteomics in selected neurodegenerative disorders: from its infancy to future applications. Antioxid Redox Signal. 2012; 17:1610-1655. [PubMed: 22115501]

21. Di Domenico F, Pupo G, Tramutola A, Giorgi A, Schinina ME, Coccia R, Head E, Butterfield DA, Perluigi M. Redox proteomics analysis of HNE-modified proteins in Down syndrome brain: clues for understanding the development of Alzheimer disease. Free Radic Biol Med. 2014; 71:270-280. [PubMed: 24675226] 
22. Perluigi M, Di Domenico F, Buttterfield DA. Unraveling the complexity of neurodegeneration in brains of subjects with Down syndrome: insights from proteomics. Proteomics Clin Appl. 2014; 8:73-85. [PubMed: 24259517]

23. Montine TJ, Neely MD, Quinn JF, Beal MF, Markesbery WR, Roberts LJ, Morrow JD. Lipid peroxidation in aging brain and Alzheimer's disease. Free Radic Biol Med. 2002; 33:620-626. [PubMed: 12208348]

24. Halliwell B. Reactive oxygen species in living systems: source, biochemistry, and role in human disease. Am J Med. 1991; 91:14S-22S.

25. Hansford RG, Hogue BA, Mildaziene V. Dependence of $\mathrm{H} 2 \mathrm{O} 2$ formation by rat heart mitochondria on substrate availability and donor age. J Bioenerg Biomembr. 1997; 29:89-95. [PubMed: 9067806]

26. Valenti D, Manente GA, Moro L, Marra E, Vacca RA. Deficit of complex I activity in human skin fibroblasts with chromosome 21 trisomy and overproduction of reactive oxygen species by mitochondria: involvement of the cAMP/PKA signalling pathway. Biochem J. 2011; 435:679-688. [PubMed: 21338338]

27. de Haan JB, Cristiano F, Iannello RC, Kola I. Cu/Zn-superoxide dismutase and glutathione peroxidase during aging. Biochem Mol Biol Int. 1995; 35:1281-1297. [PubMed: 7492966]

28. Theuns J, Van Broeckhoven C. Transcriptional regulation of Alzheimer's disease genes: implications for susceptibility. Hum Mol Genet. 2000; 9:2383-2394. [PubMed: 11005793]

29. O'Brien RJ, Wong PC. Amyloid precursor protein processing and Alzheimer's disease. Annu Rev Neurosci. 2011; 34:185-204. [PubMed: 21456963]

30. Moreira PI, Carvalho C, Zhu X, Smith MA, Perry G. Mitochondrial dysfunction is a trigger of Alzheimer's disease pathophysiology. Biochim Biophys Acta. 2010; 1802:2-10. [PubMed: 19853658]

31. Butterfield DA, Drake J, Pocernich C, Castegna A. Evidence of oxidative damage in Alzheimer's disease brain: central role for amyloid beta-peptide. Trends Mol Med. 2001; 7:548-554. [PubMed: 11733217]

32. Swomley AM, Forster S, Keeney JT, Triplett J, Zhang Z, Sultana R, Butterfield DA. Abeta, oxidative stress in Alzheimer disease: evidence based on proteomics studies. Biochim Biophys Acta. 2014; 1842:1248-1257. [PubMed: 24120836]

33. Lott IT. Antioxidants in Down syndrome. Biochim Biophys Acta. 2012; 1822:657-663. [PubMed: 22206998]

34. Muchova J, Zitnanova I, Durackova Z. Oxidative stress and Down syndrome. Do antioxidants play a role in therapy? Physiol Res. 2014; 63:535-542. [PubMed: 24908086]

35. Nunomura A, Perry G, Pappolla MA, Friedland RP, Hirai K, Chiba S, Smith MA. Neuronal oxidative stress precedes amyloid-beta deposition in Down syndrome. J Neuropathol Exp Neurol. 2000; 59:1011-1017. [PubMed: 11089579]

36. Tolun AA, Scarbrough PM, Zhang H, McKillop JA, Wang F, Kishnani PS, Millington DS, Young SP, Il'yasova D. Systemic oxidative stress, as measured by urinary allantoin and F(2)-isoprostanes, is not increased in Down syndrome. Ann Epidemiol. 2012; 22:892-894. [PubMed: 23063134]

37. Perluigi M, Swomley AM, Butterfield DA. Redox proteomics and the dynamic molecular landscape of the aging brain. Ageing Res Rev. 2013

38. Butterfield DA, Gu L, Di Domenico F, Robinson RA. Mass spectrometry and redox proteomics: applications in disease. Mass spectrometry reviews. 2014; 33:277-301. [PubMed: 24930952]

39. Di Domenico F, Perluigi M, Butterfield DA. Redox Proteomics in Human Biofluids: Sample Preparation, Separation and Immunochemical Tagging for Analysis of Protein Oxidation. Methods Mol Biol. 2016; 1303:391-403. [PubMed: 26235080]

40. Perluigi M, Butterfield DA. The identification of protein biomarkers for oxidative stress in Down syndrome. Expert review of proteomics. 2011; 8:427-429. [PubMed: 21819296]

41. Butterfield DA, Di Domenico F, Swomley AM, Head E, Perluigi M. Redox proteomics analysis to decipher the neurobiology of Alzheimer-like neurodegeneration: overlaps in Down's syndrome and Alzheimer's disease brain. Biochem J. 2014; 463:177-189. [PubMed: 25242166] 
42. Tramutola A, Di Domenico F, Barone E, Giorgi A, Di Francesco L, Schinina E, Coccia R, Arena A, Head E, Butterfield DA, Perluigi M. Poly-Ubiquitinylation Profile in Down Syndrome Brain before and after the Development of Alzheimer Neuropathology. Antioxid Redox Signal. 2016

43. Di Domenico F, De Marco F, Perluigi M. Proteomics strategies to analyze HPV-transformed cells: relevance to cervical cancer. Expert review of proteomics. 2013; 10:461-472. [PubMed: 24117203]

44. Di Domenico F, Coccia R, Butterfield DA, Perluigi M. Circulating biomarkers of protein oxidation for Alzheimer disease: expectations within limits. Biochimica et biophysica acta. 2011; 1814:1785-1795. [PubMed: 22019699]

45. Perluigi M, di Domenico F, Fiorini A, Cocciolo A, Giorgi A, Foppoli C, Butterfield DA, Giorlandino M, Giorlandino C, Schinina ME, Coccia R. Oxidative stress occurs early in Down syndrome pregnancy: A redox proteomics analysis of amniotic fluid. Proteomics Clin Appl. 2011; 5:167-178. [PubMed: 21360684]

46. Di Domenico F, Coccia R, Cocciolo A, Murphy MP, Cenini G, Head E, Butterfield DA, Giorgi A, Schinina ME, Mancuso C, Cini C, Perluigi M. Impairment of proteostasis network in Down syndrome prior to the development of Alzheimer's disease neuropathology: redox proteomics analysis of human brain. Biochim Biophys Acta. 2013; 1832:1249-1259. [PubMed: 23603808]

47. Cheon MS, Fountoulakis M, Dierssen M, Ferreres JC, Lubec G. Expression profiles of proteins in fetal brain with Down syndrome. Journal of neural transmission. Supplementum. 2001:311-319. [PubMed: 11771754]

48. Peyrl A, Weitzdoerfer R, Gulesserian T, Fountoulakis M, Lubec G. Aberrant expression of signaling-related proteins 14-3-3 gamma and RACK1 in fetal Down syndrome brain (trisomy 21). Electrophoresis. 2002; 23:152-157. [PubMed: 11824616]

49. Bajo M, Fruehauf J, Kim SH, Fountoulakis M, Lubec G. Proteomic evaluation of intermediary metabolism enzyme proteins in fetal Down's syndrome cerebral cortex. Proteomics. 2002; 2:15391546. [PubMed: 12442254]

50. Shin JH, Krapfenbauer K, Lubec G. Mass-spectrometrical analysis of proteins encoded on chromosome 21 in human fetal brain. Amino acids. 2006; 31:435-447. [PubMed: 16622604]

51. Sun Y, Dierssen M, Toran N, Pollak DD, Chen WQ, Lubec G. A gel-based proteomic method reveals several protein pathway abnormalities in fetal Down syndrome brain. Journal of proteomics. 2011; 74:547-557. [PubMed: 21262400]

52. Cenini G, Fiorini A, Sultana R, Perluigi M, Cai J, Klein JB, Head E, Butterfield DA. An investigation of the molecular mechanisms engaged before and after the development of Alzheimer disease neuropathology in Down syndrome: a proteomics approach. Free radical biology \& medicine. 2014; 76:89-95. [PubMed: 25151119]

53. Kadota M, Nishigaki R, Wang CC, Toda T, Shirayoshi Y, Inoue T, Gojobori T, Ikeo K, Rogers MS, Oshimura M. Proteomic signatures and aberrations of mouse embryonic stem cells containing a single human chromosome 21 in neuronal differentiation: an in vitro model of Down syndrome. Neuroscience. 2004; 129:325-335. [PubMed: 15501590]

54. Shin JH, Gulesserian T, Verger E, Delabar JM, Lubec G. Protein dysregulation in mouse hippocampus polytransgenic for chromosome 21 structures in the Down Syndrome Critical Region. Journal of proteome research. 2006; 5:44-53. [PubMed: 16396494]

55. Wang Y, Mulligan C, Denyer G, Delom F, Dagna-Bricarelli F, Tybulewicz VL, Fisher EM, Griffiths WJ, Nizetic D, Groet J. Quantitative proteomics characterization of a mouse embryonic stem cell model of Down syndrome. Molecular \& cellular proteomics : MCP. 2009; 8:585-595. [PubMed: 19001410]

56. Ishihara K, Kanai S, Sago H, Yamakawa K, Akiba S. Comparative proteomic profiling reveals aberrant cell proliferation in the brain of embryonic Ts1Cje, a mouse model of Down syndrome. Neuroscience. 2014; 281:1-15. [PubMed: 25261685]

57. Tsangaris GT, Karamessinis P, Kolialexi A, Garbis SD, Antsaklis A, Mavrou A, Fountoulakis M. Proteomic analysis of amniotic fluid in pregnancies with Down syndrome. Proteomics. 2006; 6:4410-4419. [PubMed: 16847874] 
58. Park J, Cha DH, Jung JW, Kim YH, Lee SH, Kim Y, Kim KP. Comparative proteomic analysis of human amniotic fluid supernatants with Down syndrome using mass spectrometry. Journal of microbiology and biotechnology. 2010; 20:959-967. [PubMed: 20622492]

59. Cho CK, Drabovich AP, Karagiannis GS, Martinez-Morillo E, Dason S, Dimitromanolakis A, Diamandis EP. Quantitative proteomic analysis of amniocytes reveals potentially dysregulated molecular networks in Down syndrome. Clinical proteomics. 2013; 10:2. [PubMed: 23394617]

60. Nagalla SR, Canick JA, Jacob T, Schneider KA, Reddy AP, Thomas A, Dasari S, Lu X, Lapidus JA, Lambert-Messerlian GM, Gravett MG, Roberts CT Jr, Luthy D, Malone FD, D’Alton ME. Proteomic analysis of maternal serum in down syndrome: identification of novel protein biomarkers. Journal of proteome research. 2007; 6:1245-1257. [PubMed: 17373838]

61. Kolialexi A, Tsangaris GT, Papantoniou N, Anagnostopoulos AK, Vougas K, Bagiokos V, Antsaklis A, Mavrou A. Application of proteomics for the identification of differentially expressed protein markers for Down syndrome in maternal plasma. Prenatal diagnosis. 2008; 28:691-698. [PubMed: 18551720]

62. Kolla V, Jeno P, Moes S, Tercanli S, Lapaire O, Choolani M, Hahn S. Quantitative proteomics analysis of maternal plasma in Down syndrome pregnancies using isobaric tagging reagent (iTRAQ). Journal of biomedicine \& biotechnology. 2010; 2010:952047. [PubMed: 19902006]

63. Kang Y, Dong X, Zhou Q, Zhang Y, Cheng Y, Hu R, Su C, Jin H, Liu X, Ma D, Tian W, Li X. Identification of novel candidate maternal serum protein markers for Down syndrome by integrated proteomic and bioinformatic analysis. Prenatal diagnosis. 2012; 32:284-292. [PubMed: 22430729]

64. Heywood W, Wang D, Madgett TE, Avent ND, Eaton S, Chitty LS, Mills K. The development of a peptide SRM-based tandem mass spectrometry assay for prenatal screening of Down syndrome. Journal of proteomics. 2012; 75:3248-3257. [PubMed: 22543281]

65. Heywood WE, Madgett TE, Wang D, Wallington A, Hogg J, Mills K, Avent ND. 2D DIGE analysis of maternal plasma for potential biomarkers of Down Syndrome. Proteome science. 2011; 9:56. [PubMed: 21929753]

66. Heywood W, Mills K, Wang D, Hogg J, Madgett TE, Avent ND, Chitty LS. Identification of new biomarkers for Down's syndrome in maternal plasma. Journal of proteomics. 2012; 75:2621-2628. [PubMed: 22456345]

67. Yu B, Zhang B, Wang J, Wang QW, Huang RP, Yang YQ, Shao SH. Preliminary proteomic-based identification of a novel protein for Down's syndrome in maternal serum. Experimental biology and medicine. 2012; 237:530-539. [PubMed: 22678011]

68. Tramutola A, Di Domenico F, Barone E, Perluigi M, Butterfield DA. It Is All about (U)biquitin: Role of Altered Ubiquitin-Proteasome System and UCHL1 in Alzheimer Disease. Oxid Med Cell Longev. 2016; 2016:2756068. [PubMed: 26881020]

69. Di Domenico F, Tramutola A, Perluigi M. Cathepsin D as a therapeutic target in Alzheimer's disease. Expert Opin Ther Targets. 2016; 20:1393-1395. [PubMed: 27805462]

70. Di Domenico F, Head E, Butterfield DA, Perluigi M. Oxidative Stress and Proteostasis Network: Culprit and Casualty of Alzheimer's-Like Neurodegeneration. Advances in Geriatrics. 2014; 2014:14.

71. Perluigi M, Di Domenico F, Butterfield DA. mTOR signaling in aging and neurodegeneration: At the crossroad between metabolism dysfunction and impairment of autophagy. Neurobiology of disease. 2015; 84:39-49. [PubMed: 25796566]

72. Perluigi M, Pupo G, Tramutola A, Cini C, Coccia R, Barone E, Head E, Butterfield DA, Di Domenico F. Neuropathological role of PI3K/Akt/mTOR axis in Down syndrome brain. Biochim Biophys Acta. 2014; 1842:1144-1153. [PubMed: 24735980]

73. Butterfield DA, Lauderback CM. Lipid peroxidation and protein oxidation in Alzheimer's disease brain: potential causes and consequences involving amyloid beta-peptide-associated free radical oxidative stress. Free Radic Biol Med. 2002; 32:1050-1060. [PubMed: 12031889]

74. Ishihara K, Amano K, Takaki E, Ebrahim AS, Shimohata A, Shibazaki N, Inoue I, Takaki M, Ueda Y, Sago H, Epstein CJ, Yamakawa K. Increased lipid peroxidation in Down's syndrome mouse models. Journal of neurochemistry. 2009; 110:1965-1976. [PubMed: 19645748] 
75. Di Domenico F, Pupo G, Mancuso C, Barone E, Paolini F, Arena A, Blarzino C, Schmitt FA, Head E, Butterfield DA, Perluigi M. Bach1 overexpression in Down syndrome correlates with the alteration of the HO-1/BVR-a system: insights for transition to Alzheimer's disease. J Alzheimers Dis. 2015; 44:1107-1120. [PubMed: 25391381]

76. Ponka P. Rare causes of hereditary iron overload. Semin Hematol. 2002; 39:249-262. [PubMed: 12382200]

77. Chiueh CC. Iron overload, oxidative stress, and axonal dystrophy in brain disorders. Pediatr Neurol. 2001; 25:138-147. [PubMed: 11551744]

78. Beard JL, Connor JR, Jones BC. Iron in the brain. Nutr Rev. 1993; 51:157-170. [PubMed: 8371846]

79. Beard J. Iron deficiency alters brain development and functioning. J Nutr. 2003; 133:1468S-1472S. [PubMed: 12730445]

80. Goldstein L, Teng ZP, Zeserson E, Patel M, Regan RF. Hemin induces an iron-dependent, oxidative injury to human neuron-like cells. J Neurosci Res. 2003; 73:113-121. [PubMed: 12815715]

81. Van Bergen P, Rauhala P, Spooner CM, Chiueh CC. Hemoglobin and iron-evoked oxidative stress in the brain: protection by bile pigments, manganese and S-nitrosoglutathione. Free Radic Res. 1999; 31:631-640. [PubMed: 10630686]

82. Rouault TA. Iron metabolism in the CNS: implications for neurodegenerative diseases. Nat Rev Neurosci. 2013; 14:551-564. [PubMed: 23820773]

83. Ziegler EE, Nelson SE, Jeter JM. Iron supplementation of breastfed infants from an early age. Am J Clin Nutr. 2009; 89:525-532. [PubMed: 19073791]

84. Lozoff B, Georgieff MK. Iron deficiency and brain development. Semin Pediatr Neurol. 2006; 13:158-165. [PubMed: 17101454]

85. Carter RC, Jacobson JL, Burden MJ, Armony-Sivan R, Dodge NC, Angelilli ML, Lozoff B, Jacobson SW. Iron deficiency anemia and cognitive function in infancy. Pediatrics. 2010; 126:e427-434. [PubMed: 20660551]

86. Hare DJ, Arora M, Jenkins NL, Finkelstein DI, Doble PA, Bush AI. Is early-life iron exposure critical in neurodegeneration? Nat Rev Neurol. 2015; 11:536-544. [PubMed: 26100754]

87. Peters DG, Connor JR, Meadowcroft MD. The relationship between iron dyshomeostasis and amyloidogenesis in Alzheimer's disease: Two sides of the same coin. Neurobiol Dis. 2015; 81:4965. [PubMed: 26303889]

88. David O, Fiorucci GC, Tosi MT, Altare F, Valori A, Saracco P, Asinardi P, Ramenghi U, Gabutti V. Hematological studies in children with Down syndrome. Pediatr Hematol Oncol. 1996; 13:271275. [PubMed: 8735344]

89. Wachtel TJ, Pueschel SM. Macrocytosis in Down syndrome. Am J Ment Retard. 1991; 95:417420. [PubMed: 1825915]

90. Manna C, Officioso A, Trojsi F, Tedeschi G, Leoncini S, Signorini C, Ciccoli L, De Felice C. Increased non-protein bound iron in Down syndrome: contribution to lipid peroxidation and cognitive decline. Free Radic Res. 2016:1-10.

91. Prasher VP, Gosling P, Blair J. Role of iron in Alzheimer-type dementia in Down syndrome. Int J Geriatr Psychiatry. 1998; 13:818-819. [PubMed: 9850881]

92. Anneren G, Gebre-Medhin M. Trace elements and transport proteins in serum of children with Down syndrome and of healthy siblings living in the same environment. Hum Nutr Clin Nutr. 1987; 41:291-299. [PubMed: 2442124]

93. Kedziora J, Witas H, Bartosz G, Leyko W, Jeske J, Rozynkowa D. Down syndrome - transferrin parallels plasma iron changes. Experientia. 1978; 34:712-713. [PubMed: 149016]

94. Fuqua BK, Vulpe CD, Anderson GJ. Intestinal iron absorption. J Trace Elem Med Biol. 2012; 26:115-119. [PubMed: 22575541]

95. Wang J, Pantopoulos K. Regulation of cellular iron metabolism. Biochem J. 2011; 434:365-381. [PubMed: 21348856]

96. Musci G, Polticelli F, Bonaccorsi di Patti MC. Ceruloplasmin-ferroportin system of iron traffic in vertebrates. World J Biol Chem. 2014; 5:204-215. [PubMed: 24921009] 
97. Patel BN, Dunn RJ, Jeong SY, Zhu Q, Julien JP, David S. Ceruloplasmin regulates iron levels in the CNS and prevents free radical injury. J Neurosci. 2002; 22:6578-6586. [PubMed: 12151537]

98. Jeong SY, David S. Age-related changes in iron homeostasis and cell death in the cerebellum of ceruloplasmin-deficient mice. J Neurosci. 2006; 26:9810-9819. [PubMed: 16988052]

99. Brissot P, Ropert M, Le Lan C, Loreal O. Non-transferrin bound iron: a key role in iron overload and iron toxicity. Biochim Biophys Acta. 2012; 1820:403-410. [PubMed: 21855608]

100. Levi S, Finazzi D. Neurodegeneration with brain iron accumulation: update on pathogenic mechanisms. Front Pharmacol. 2014; 5:99. [PubMed: 24847269]

101. Aisen P, Leibman A, Zweier J. Stoichiometric and site characteristics of the binding of iron to human transferrin. J Biol Chem. 1978; 253:1930-1937. [PubMed: 204636]

102. Huebers HA, Finch CA. The physiology of transferrin and transferrin receptors. Physiol Rev. 1987; 67:520-582. [PubMed: 3550839]

103. Kawabata H, Yang R, Hirama T, Vuong PT, Kawano S, Gombart AF, Koeffler HP. Molecular cloning of transferrin receptor 2. A new member of the transferrin receptor-like family. J Biol Chem. 1999; 274:20826-20832. [PubMed: 10409623]

104. Waldvogel-Abramowski S, Waeber G, Gassner C, Buser A, Frey BM, Favrat B, Tissot JD. Physiology of iron metabolism. Transfus Med Hemother. 2014; 41:213-221. [PubMed: 25053935]

105. Gozzelino R, Soares MP. Coupling heme and iron metabolism via ferritin H chain. Antioxid Redox Signal. 2014; 20:1754-1769. [PubMed: 24124891]

106. Bogdan AR, Miyazawa M, Hashimoto K, Tsuji Y. Regulators of Iron Homeostasis: New Players in Metabolism, Cell Death, and Disease. Trends Biochem Sci. 2016; 41:274-286. [PubMed: 26725301]

107. Kolialexi A, Vrettou C, Traeger-Synodinos J, Burgemeister R, Papantoniou N, Kanavakis E, Antsaklis A, Mavrou A. Noninvasive prenatal diagnosis of beta-thalassaemia using individual fetal erythroblasts isolated from maternal blood after enrichment. Prenat Diagn. 2007; 27:12281232. [PubMed: 17987605]

108. Hattori Y, Mukaide T, Jiang L, Kotani T, Tsuda H, Mano Y, Sumigama S, Hirayama T, Nagasawa H, Kikkawa F, Toyokuni S. Catalytic ferrous iron in amniotic fluid as a predictive marker of human maternal-fetal disorders. J Clin Biochem Nutr. 2015; 56:57-63. [PubMed: 25678752]

109. Bielli P, Calabrese L. Structure to function relationships in ceruloplasmin: a 'moonlighting' protein. Cell Mol Life Sci. 2002; 59:1413-1427. [PubMed: 12440766]

110. Kang JH, Kim KS, Choi SY, Kwon HY, Won MH. Oxidative modification of human ceruloplasmin by peroxyl radicals. Biochim Biophys Acta. 2001; 1568:30-36. [PubMed: 11731082]

111. Aouffen M, Paquin J, Furtos A, Waldron KC, Mateescu MA. Oxidative aggregation of ceruloplasmin induced by hydrogen peroxide is prevented by pyruvate. Free Radic Res. 2004; 38:19-26. [PubMed: 15061650]

112. Lozoff B, Beard J, Connor J, Barbara F, Georgieff M, Schallert T. Long-lasting neural and behavioral effects of iron deficiency in infancy. Nutr Rev. 2006; 64:S34-43. discussion S72-91. [PubMed: 16770951]

113. Connor JR, Menzies SL. Cellular management of iron in the brain. J Neurol Sci. 1995; 134(Suppl):33-44.

114. Maines MD. The heme oxygenase system: a regulator of second messenger gases. Annu Rev Pharmacol Toxicol. 1997; 37:517-554. [PubMed: 9131263]

115. Maines MD. The heme oxygenase system: update 2005. Antioxid Redox Signal. 2005; 7:17611766. [PubMed: 16356137]

116. Barone E, Butterfield DA. Insulin resistance in Alzheimer disease: Is heme oxygenase-1 an Achille's heel? Neurobiol Dis. 2015; 84:69-77. [PubMed: 25731746]

117. Barone E, Di Domenico F, Mancuso C, Butterfield DA. The Janus face of the heme oxygenase/ biliverdin reductase system in Alzheimer disease: it's time for reconciliation. Neurobiol Dis. 2014; 62:144-159. [PubMed: 24095978]

118. Mancuso C, Barone E. The heme oxygenase/biliverdin reductase pathway in drug research and development. Curr Drug Metab. 2009; 10:579-594. [PubMed: 19702533] 
119. Seixas E, Gozzelino R, Chora A, Ferreira A, Silva G, Larsen R, Rebelo S, Penido C, Smith NR, Coutinho A, Soares MP. Heme oxygenase-1 affords protection against noncerebral forms of severe malaria. Proc Natl Acad Sci U S A. 2009; 106:15837-15842. [PubMed: 19706490]

120. Larsen R, Gozzelino R, Jeney V, Tokaji L, Bozza FA, Japiassu AM, Bonaparte D, Cavalcante MM, Chora A, Ferreira A, Marguti I, Cardoso S, Sepulveda N, Smith A, Soares MP. A central role for free heme in the pathogenesis of severe sepsis. Sci Transl Med. 2010; 2:51ra71.

121. Ganz T. Hepcidin and iron regulation, 10 years later. Blood. 2011; 117:4425-4433. [PubMed: 21346250]

122. Gozzelino R, Andrade BB, Larsen R, Luz NF, Vanoaica L, Seixas E, Coutinho A, Cardoso S, Rebelo S, Poli M, Barral-Netto M, Darshan D, Kuhn LC, Soares MP. Metabolic adaptation to tissue iron overload confers tolerance to malaria. Cell Host Microbe. 2012; 12:693-704. [PubMed: 23159058]

123. Gozzelino R, Jeney V, Soares MP. Mechanisms of cell protection by heme oxygenase-1. Annu Rev Pharmacol Toxicol. 2010; 50:323-354. [PubMed: 20055707]

124. Wilcock DM, Hurban J, Helman AM, Sudduth TL, McCarty KL, Beckett TL, Ferrell JC, Murphy MP, Abner EL, Schmitt FA, Head E. Down syndrome individuals with Alzheimer's disease have a distinct neuroinflammatory phenotype compared to sporadic Alzheimer's disease. Neurobiol Aging. 2015; 36:2468-2474. [PubMed: 26103884]

125. Di Fonzo A, Chien HF, Socal M, Giraudo S, Tassorelli C, Iliceto G, Fabbrini G, Marconi R, Fincati E, Abbruzzese G, Marini P, Squitieri F, Horstink MW, Montagna P, Libera AD, Stocchi F, Goldwurm S, Ferreira JJ, Meco G, Martignoni E, Lopiano L, Jardim LB, Oostra BA, Barbosa ER, Bonifati V. Italian Parkinson Genetics N. ATP13A2 missense mutations in juvenile parkinsonism and young onset Parkinson disease. Neurology. 2007; 68:1557-1562. [PubMed: 17485642]

126. Ramirez A, Heimbach A, Grundemann J, Stiller B, Hampshire D, Cid LP, Goebel I, Mubaidin AF, Wriekat AL, Roeper J, Al-Din A, Hillmer AM, Karsak M, Liss B, Woods CG, Behrens MI, Kubisch C. Hereditary parkinsonism with dementia is caused by mutations in ATP13A2, encoding a lysosomal type 5 P-type ATPase. Nat Genet. 2006; 38:1184-1191. [PubMed: 16964263]

127. Di Domenico F, Sultana R, Ferree A, Smith K, Barone E, Perluigi M, Coccia R, Pierce W, Cai J, Mancuso C, Squillace R, Wiengele M, Dalle-Donne I, Wolozin B, Butterfield DA. Redox proteomics analyses of the influence of co-expression of wild-type or mutated LRRK2 and Tau on C. elegans protein expression and oxidative modification: relevance to Parkinson disease. Antioxid Redox Signal. 2012; 17:1490-1506. [PubMed: 22315971]

128. Hvidberg V, Maniecki MB, Jacobsen C, Hojrup P, Moller HJ, Moestrup SK. Identification of the receptor scavenging hemopexin-heme complexes. Blood. 2005; 106:2572-2579. [PubMed: 15947085]

129. Kristiansen M, Graversen JH, Jacobsen C, Sonne O, Hoffman HJ, Law SK, Moestrup SK. Identification of the haemoglobin scavenger receptor. Nature. 2001; 409:198-201. [PubMed: 11196644]

130. Duce JA, Tsatsanis A, Cater MA, James SA, Robb E, Wikhe K, Leong SL, Perez K, Johanssen T, Greenough MA, Cho HH, Galatis D, Moir RD, Masters CL, McLean C, Tanzi RE, Cappai R, Barnham KJ, Ciccotosto GD, Rogers JT, Bush AI. Iron-export ferroxidase activity of betaamyloid precursor protein is inhibited by zinc in Alzheimer's disease. Cell. 2010; 142:857-867. [PubMed: 20817278] 


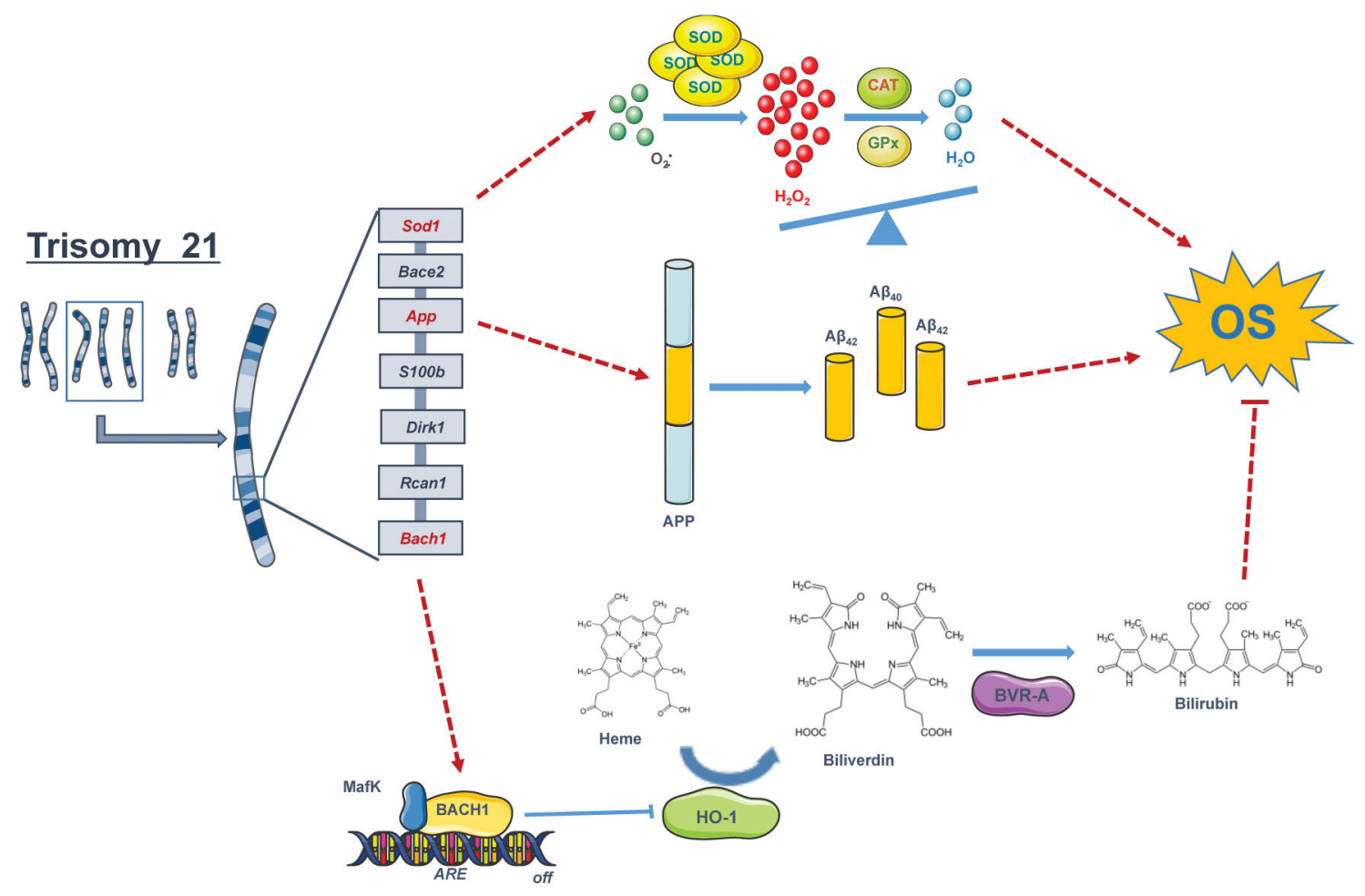

Figure 1. Trisomy 21-induced oxidative stress

Schematic representation of a sub set of trisomic genes that are associate dwith increased oxidative stress (OS) conditions. In detail, SOD1, APP and BACH1 are the triplicated genes that are discussed in the review. $S O D 1$ encodes for the enzyme superoxide dismutase; $A P P$ fort the amyloid precursor protein; and $B A C H 1$ for the transcription repressor $\mathrm{BACH} 1$ that bind to the antioxidant response elements (AREs) of DNA thus suppressing the induction of HO-1 and other antioxidant proteins.

$\mathrm{CAT}=$ catalase GPX= glutathione peroxidase; $\mathrm{HO}-1=$ heme oxygenase $1 ; \mathrm{BVR}-\mathrm{A}=$ biliverdin reductase A;

Free Radic Biol Med. Author manuscript; available in PMC 2019 January 01. 


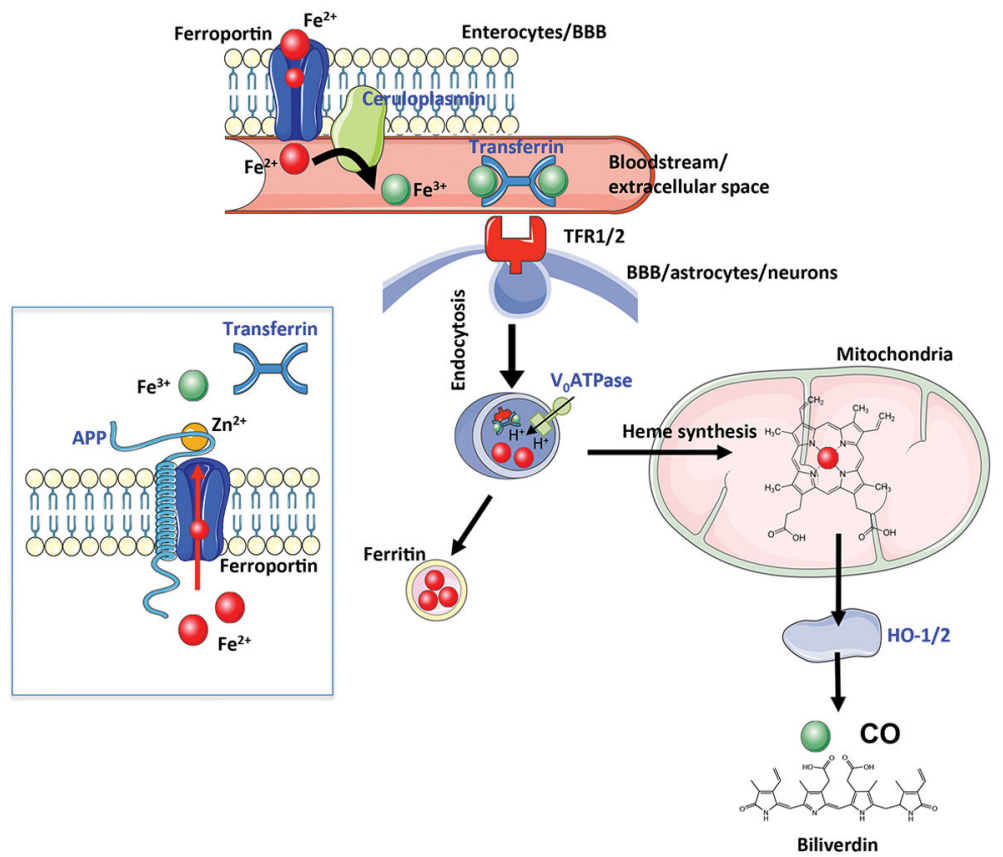

Figure 2. Schematic overview of the main iron metabolic pathways possibly involved in Down Syndrome neurodegeneration

In blue, proteins found to be altered in Down Syndrome. APP, amyloid precursor protein; $\mathrm{BBB}$, blood brain barrier; $\mathrm{CO}$, carbon monoxide; TFR-1/2, transferrin receptor-1/2; 